\title{
On The Twelfth and Fifteenth Itinera Of Antoninus
}

\section{J. B. Davidson M.A.}

To cite this article: J. B. Davidson M.A. (1880) On The Twelfth and Fifteenth Itinera Of Antoninus, Archaeological Journal, 37:1, 300-319, DOI: 10.1080/00665983.1880.10851940

To link to this article: http://dx.doi.org/10.1080/00665983.1880.10851940

曲 Published online: 14 Jul 2014.

Submit your article to this journal 저

Q View related articles $₫$ 


\section{ON THE TWELFTH ANI FIFTEENTH ITINERA OF ANTONINUS,}

\section{By J. B. DAVIDSON, M.A.}

A revived interest appears to be felt in this old and much debated subject. At the meeting of the Somerset Archæological Society at Bruton, in 1878, a paper on the Twelfth Iter was read by the Hon. and Rt. Rev. Bishop Clifford ; and in the September number of the Journal of the Archæological Association for 1876, in an article by Mr. Gordon II. Hills, ${ }^{2}$ several of the Itinera are dealt with, but Nos. VII, and especially XV, are presented under very striking features of novelty.

Those who are acquainted with the matter are aware that there are questions arising upon the Twelfth Iter which are affected by the Fifteenth, and that the former cannot be satisfactorily discussed without taking the latter into consideration.

Now upon reading the treatises referred to, there is one thing which cannot fail to strike attention, namely, that the writers have put forward their theories without reference to the labours of their preclecessors in the same field. Each expositor starts from his own point of view, regardless of what may be conceived to be the successes, and what the failures of former essayists. Yet the matters at issue have a tradition. They were very industrionsly studied in times past, and have been abundantly illustratel by a long series of modern observations. All that we here desire to clo is to state the case as it was considered by the men of old, as compared with the way in which it presents itself to us, in the hope of shewing that, notwithstanding the innovations to which we have adverted, a consensus has been actually arrived at on the main particulars involved, if not as to all the minor details.

Talking then the Fifteenth, ${ }^{3}$ which happens also to be the last, of the Itinera relating to Britain, and employing for the present, the text of MiI. Parthey and Pinder, we find that it stands as follows :-

\begin{tabular}{|c|c|c|c|c|c|}
\hline \multicolumn{6}{|c|}{ (Iter XT.) } \\
\hline Vindomi & - & - & & $\mathrm{m} \mathrm{p} \mathrm{m}$ & xv \\
\hline Venta Belgaru & & - & & $\mathrm{mp} \mathrm{m}$ & $\mathrm{xxi}$ \\
\hline Brige & - & - & & $\mathrm{m} \mathrm{p} \mathrm{m}$ & $\mathrm{xi}$ \\
\hline Sorbiocloni & - & - & & $\mathrm{m} \mathrm{p} \mathrm{m}$ & viii \\
\hline Vindogladia & - & - & & $\mathrm{m} \mathrm{p} \mathrm{m}$ & xii \\
\hline Dumorovaria & - & - & & in $\mathrm{p}$ in & viii \\
\hline Muriduno & - & - & & $\mathrm{mpm}$ & xxxvi \\
\hline Isca Dumnunio & prum & - & & $\mathrm{mpm}$ & $x y^{\prime \prime}$ \\
\hline
\end{tabular}

1 "Course of a Romm Military Road through Somersetshire" ; Proceedings Som. Arch. Soc., N.S., vol. iv, p. 22.

2 "Measurements of Ptolemy and the Antonine Itinerary;" Journal of the

Arch. Assoc, vol. xxxiv, p. 271.

3 The numbering from 1 to 15 , commonly and most usefully adopted is, we meed scarcely say, quite an assumption, and hiss no warrant in the original. 
The sum of the station distances is 126 miles, being less than the summary given in the title by ten miles.

Now if we tum back to the Twelfth Iter, still for the present using the text of MMI. Parthey and Pinder, we find that it presents itself as follows :-

"Item a Muridumo Viroconium (Iter XII.)

\begin{tabular}{|c|c|c|c|c|c|}
\hline Vindomi & - & - & - & $\mathrm{mp} \mathrm{p}$ & $\mathrm{xv}$ \\
\hline Venta Belga & $1 \mathrm{~m}$ & - & - & $\mathrm{mpm}$ & $\mathrm{xxi}$ \\
\hline Brige & - & - & - & $\mathrm{mp} \mathrm{m}$ & $\mathrm{xi}$ \\
\hline Sorvioclumi & - & - & - & $\mathrm{mp} \mathrm{m}$ & viii \\
\hline Vindogladia & - & - & - & $\mathrm{m} \mathrm{pm}$ & xii \\
\hline Durnonovar & - & - & - & $\mathrm{mpm}$ & viii \\
\hline Muriduno & - & - & - & $\mathrm{mpm}$ & xxxvi \\
\hline Isca Dumnu & iorum & - & - & $m p m$ & $\mathrm{xv}$ \\
\hline Leucaro & - & - & - & $m p m$ & $\mathrm{xv}$ \\
\hline Nido & - & - & - & $\mathrm{mpm}$ & $\mathrm{xV}$ \\
\hline Bomio & - & - & - & $\mathrm{m} \tilde{\mathrm{p}}$ & $\mathrm{xv}$ \\
\hline Isca leg. II & Iugusta & - & - & $m p m$ & xxvii \\
\hline Bulrio & - & - & - & $\mathrm{m} \mathrm{p} \mathrm{m}$ & viiii \\
\hline Gobamnio & - & - & - & $\mathrm{m} \mathrm{p}$ m & xii \\
\hline Magnis & - & - & - & $\mathrm{mpm}$ & xxii \\
\hline Bravonio & - & - & - & $\mathrm{m} \mathrm{p} \mathrm{m}$ & xxiiii \\
\hline Viroconio & - & - & - & $\mathrm{mp} \mathrm{m}$ & xxvii" \\
\hline
\end{tabular}

Here we are struck with the circumstance that Iter XII consists of precisely the same eight stations as those of $\mathrm{XV}$, with nine more stations appended to them, so that Isca Dumnumiorum, which is the terminal station of XV, becomes an intermediate station of XII. Moreover, one particular place, Muridunum, which is an intermediate station of XV and also of XII, appears as the name of the initial station or starting point of XII. The station distances of XII, also, make together 292 miles, the number in the summary being only 186 miles.

This however does not exhaust the question. There prevails a difference of anthority as to the proper reading of the heacling of Iter XII. Bishop Clifford, in the paper referred to above, ${ }^{1}$ cites it thus :- " Iter xii a Caleva per Muridunum Vericomium M. P. CCLXXXvi." As a great deal turns upon what the true reading of this heading or title is, we propose to examine briefly the authorities on the point.

\section{On the Reading of the Heading of Iter XII,}

The first printed edition of the Itinerary is that of $\mathrm{H}$. Stephanus, Paris, 1512. It recoived the corrections of Christopher Longueil, and is the editio princeps. Copies exist in the Grenville Library and in the Bodleian. This edition gives the following as the heading of the Twelfth Iter :-

$$
\begin{aligned}
& \text { "Iter" a Muridono Viroconiorum } \\
& 186^{2} \\
& \text { milia plus minus ; 286, sic .." }
\end{aligned}
$$

1 Page 23.

2 The number 186 is inserted above
286 , evidently by way of proposed emendation. 
In like manner the Aldine edition of 1518 , the Florentine of 1519 , the Lyons edition, undated, but probalbly of 1536 , and the edition published at Basle in 1575, with Simler's notes, all read, "Item a Muridono Viroconiorum M. P. CCLXXXVI, sic ..."

Hitherto no printed edition of the Itinerary had mentioned Calleva in the heading of Iter XII; but Simler, in his notes to the Basle edition of 1575, observes:- "In Scudii' exemplari, 'A Caleva per Muridunum Viroconium,' atque ita rectius legitur, nam Muridunum vel Moriclunum in medio hoc itinere ponitur."

This is the first we hear of Calleva in the heading of the Iter; and the first occasion of its appenrance in print is believed to be the English publication in 1577 of Holinshed's Chronicle, by Harrison. At the end of the "Thircle Booke" of the "Description of Britaine," after a table of English roads, the reacler is, very appropriately, treated to a version of the Itinerary, and in that version the following is given as the heading of Iter XII :- "Item a Caleva alias Muriclono alias Viroconoriorum," a reading which may be at once set aside as hopelessly unauthorized and wrong.

Next in orcler of clate comes the Cologne edition of 1600, published by Andrew Schott, with notes by the Spanish scholar, Hieronymus Surita; and next the sumptuous Leyden edition, in 1618, by Peter Bert, geographer to Louis XIII. Then follows, in 1658, a commentary by our countryman William Burton, schoolmaster, of Kingston-onThames. Neither of these editions contains any mention of Calleva in the heading of the Twelfth Iter.

We are thus brought down to the era of Dr. Gale, whose work marks a new departure in the literature of the subject. Dr. Gale died Dean of York in 1709, and in the same year his posthumous treatise on the Itinerary was published by Roger Gale, his son. The authorities upon which Dr. Gale is represented to have relied are :-Two MSS. from the King's Library at Paris; readings from a copy of the work of Surita, which had been collated by Dr. Richardson, master of Peterhouse, Cambrilge, with MISS. of Isaac Tossius ; and, thirdly, readings attributed to Bentley, and taken from what is called the "Atrebatensian MS."

Whether Simler's note influenced Dr. Gale, or whatever his reason was, there is no cloubt that he cloes read" the heading of XII as follows:

\section{"ITER XiI. \\ A CALLEVA MURIDUNO URIOCONIUM M. P. CLXXXVI."}

and that he dicl adopt this reading, is little less than a calamity, for his conclusion, as will be seen, not only misled Horsley, and through Horsley, the foreign editors, Wesseling and Mannert, but has survived to lead topographers astray even in our own time.

Dr. Gale's error, however, did not long remain uncorrected. In the

1 The reference is to Giles Schud, of Glaris, who died in February, 1571, at the age of sixty-seven. His unfinished history of Switzerland was continued by Simler ; Teissier, Eloges, ii, 426. Schud's was probably an amnotated copy of one of the abore-mentioned editions.
2 Antonini Iter, pp. vi, 124. In the $X V$ Scriptores, by Gale and Fell, 1691, we find, on the $0^{+}$her hind, "Iter a Muriduno Viroconium," iii, App. 754. But this text professes to be merely a copy of the reading of Surita, see p. 742 . 
following year, on the 5th of December, 1710, was issued, or at least was dated prior to publication, an edition of the Itinerary by Hearne. This work appears at the end of the third volume of Leland. This will be found to be, in every respect, a laborious and conscientious performance as a piece of editing, considering the age in which it appeared, and the materials at hand. A commentary, indeed, it is not, for the modern designations of Roman names are all copied from Gale. What Hearne unclertook to do was to publish notes, which had been made a century before by the learned Richard Talbot, ${ }^{1}$ who was canon of Norwich in 1547 , and he prefaces this publication by the edition in question, which he collates with the Florentine, the Lyons, the Cologne, and Leyden editions, taking note also of Harrison and Gale, and of some ammotated copies of Surita in the Bodleian. When he comes to the Twelfth Iter, he produces the following heading:-

\section{" T ITER A $\mathrm{M}[\mathrm{V}] \mathrm{RIDONO}$ vIROco[v]Io- \\ RVM MILIA PLVS MINVS . COLXXXVI, SIC."}

where, again, we find no mention of Calleva.

Thus matters stood until the age of Stukeley and Horsley; and here, in orcler to explain the relation in which these two writers stood to each ather, it is necessary to be precise as to dates. In 1724 Dr. Stukeley first published the results of his antiquarian journeys, under the imposing title of "Itinerarium Curiosum, Centuria I." With the characteristics of this work every one is familiar. Whilst we are amused with the learned cloctor's credulity, we cannot but be grateful to him for the descriptions and illustrations he has handed down to us. Horsley's Britania Romuna followed in 1732. Horsley, who was personally unacquainted with the south-west of England, depended wholly for his topographical knowledge on Stukeley's descriptions. The latter, as he tells us, visited Bath and Exeter, where he was entertained by Dr. Musgrave; thence he made his way back along the coast to Seaton, and thence to Bridport in Dorsetshire. Fifteen years after Horsley's publication, namely, in July 1747 , Stukeley was first addressed by the notorious Charles Julius Bertram, of Copenhagen; and ten years later appeared the second edition of the "Itinerarium," with an account of the fictitious chronicle, map, and treatise $D_{e}$ Situ Brittanice, falsely ascribed to the inmocent and simple chronicler, Richard of Cirencester. The forgery, though not unsuspected, was first publicly exposed by F. C. Wex in 1845 and 1846, and more fully in 1852, having tainted the sources of history for about a century. ${ }^{2}$

Dr. Stukeley gives no edition and no version of the Roman Itineriry, but Mr. Horsley, in the Britania Romana, which is a critical, as well as a topographical work, does both; and in a disastrous hour for his reputation and success, he preferred to adopt from Gale the erroneous reading of Calleva in the heading of Iter XII, rather than to follow the uniform current of authority afforded by seven foreign editions of the first rank, and by the English works of Burton and Hearne.

1 This is said to be the first commentary extant in English. It does not go beyond Iter $\nabla$. Camden and Burton were both indebted to it; Leland, Itin., by Hearne, iii, 130.
2 See the papers in the Gentleman's Magazine for' 1866 , by the late Mr. Woodward, and the edition of Richard, by Professor John E. B. Mayor, of Cambridge, in the Rolls Series. 
In our own day, but for Bishop Clifford's authority, we should have considered the point beyond controversy. The work of MM. Parthey and Pinder, published at Berlin in 1848, seems really to close the question. These editors state that having examined a large number of codices in all parts of Europe, they selected twenty-one as the foundation for their text, giving variom notes at the foot of the page. They pledge themselves that no different reading amongst the twenty-one of their selection has been umnoticed. ${ }^{1}$ If this statement is to be accepted literally, nothing more remains to be said, for no one of the twenty-one codices contains any mention of Calleva in the heading of Iter XII.

\section{On the Eight Stations Common to Iter XII and Iter XV.}

The result just arrived at is of the first importance, for if Calleva is to find no place in the title of the Twelfth Iter, we are left with the indication that it is an Iter leading only from Muridunum to Uriconium, to which the first eight recorded stations are plainly inappropriate. How then are these eight stations to be dealt with? The only alternative is to adopt the solution of Willinu Burton, who says, writing so far back as in 1658 -

"This Author" (namely, Antoninus), "hy the heedlesness of the Litrarii or Transcribers is much abused, for they have very coursly handled him, having confounded two clistinct Journeys, the last and this same here; and this oversight and error is in every copy which is extant, and hitherto hath escaped the curious eyes of the undertakers of the several Editions of him : the main cause of the error was the ignorance of Muridunum, and the taking it for Maridumum, which is known by most to be Kaer Marthin in Wales, so that this joumey will prove from thence to Trolicester in Shropstive, and it is by Kaer-Marthin or Maprouvoy, as Ptolemy calls it here: the journey which begins Muridunum is exactly the same with the last, as you may see plainly in what comes after; neither doth Antoninus continue lis marches beyond this Marillunum. The next station which happens in this journey is Leucamm in Glamorganshire, by the river Logher, which also we now call Loghor." 2

With this view Dr. Gale, notwithstanding his retention of Calleva in the title, distinctly agrees. He says expressly ${ }^{3}$ that in this instance two Itinera have been jumbled together, one being a route starting from Calleva and encling at Isca Dumnuniorum, the other a route setting out from "Maridunum," the modern "Caerdmarlhin," being a different place from Maridunum, near Isca Dumnuniorum, which, he says, is in Devonshire, and now called Seaton. And in his table of identifications, he assigns to Leucarus, Loghor ; to Bomium, Boverton; and to Nidus, Neath in Glamorganshire.

It was Mr. Horsley's ill-fortune not to be able to agree in this plain

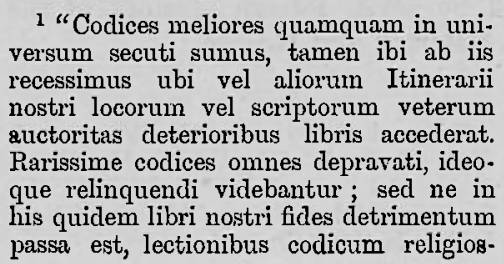

issime adscriptis. Cuiusvis enim codicis lectio aut in notis ponitur, aut, ubi non commemoratur, cum textu prorsus congruit. Igitur quod recepimus, id omnium codicum auctoritate nititur, quorum discrepantia non annotata est." -Præe., p. $x$.

"Burton, vol. i, p. 247.

${ }^{3}$ Page 124. 
and simple solution of the difficulty. He macle the double mistake of adopting the name Calleva in the title of Iter XII, and of treating No. XII as one long continuous route, reaching all the way round from Calleva to Uriconium, that is to say, from Silchester to Wroxeter. Burton and Hearne might have saved him from the former lapse; Burton and Gale from the latter. But it was not to be ; and the result was to launch this learned commentator upon a sea of difficulties, in which he not only himself laboured, but over which he has unhappily induced many others to follow him, until a subject originally clear has become clouded over with obscurity, and a series of suggestions have been placed before the world, not merely distracting from their variety but absolutely unnecessary when the nature of the question is fairly examined.

The Britannia Romana was followed abroad by the elegant edition of Peter Wesseling at Amsterdam in 1735, which, in some respects, is treated abroad as an eatitio princeps. The pagination of this edition is followed by MM. Parthey and Pinder. Wesseling gives notes indicative of the supposed modern localities. His plan manifestly was to have recourse for each country to the opus magnum on the subject which that country had produced, and thus to compile his notes. For Britrin, he naturally turned to Horsley, and accordingly we find him in his text adopting Calleva in the heading of No. XII, and in his identifications of places he invariably accepts Horsley's conclusions.

The "continuous" theory of Iter XII was in like manner, and in deference to Wesseling, adopted by Conrad Mannert. The portion of this voluminous work which relates to Britain was published at Leipsic in 1822. Probably the author never visited this country, and his interpretations seem to have been suggested only by a study of maps and station distances.

Although the soundness of Horsley's conclusions was questioned in 1754 by Dr. Borlase, who had the advantage of local knowledge, ${ }^{1}$ and clisputed by Reynolds in $1799,{ }^{2}$ yet the true source of his error, namely the "confusio" of two itinera in No. XII, seems not to have been much adverted to by English topographers of the eighteenth century. The deservedly great weight of Horsley's authority counterbalanced that of Burton and Gale. But it was not so in France. M. Lapie, writing in 1845 , brings earlier authority than his own to bear on the point. He observes, ${ }^{3}$ "La route devait, d'après les localites, s'arreter a Isca Dumnoniorum. Ce qui suit parait former une autre route partant probablement de Maridanum (Caermarthen), qui dans l'Itineraire, a put-etre confondu avec Muridunum (Salcombe Regis). Telle est clu moins l'opinion d'Anville et de M. Reichard, i laquelle nous nous rangeons volonticrs."

Ancl then, finally, MM. Parthey and Pinder deal with the matter thus. They print the first eight stations of No. XII, as we number it, in smaller type, and ald in a note the remark that these eight lines appear to have been transferred hither by mistake from the last of the British Itinera; and that the scribe ought to have gone on from the "Viroco" of "Viroconiorum " straight to the " niorum " of "Dumnumiorum," without inserting what he has inserterl between these two portions of words, for, as they observe, the reading of Viroconiorum for Viroconium appears in

1 Antiquities of Cornwall, p. 295.

2 Iter Britanniarum, p. 334.

VOL. XXXYII,
3 Page 146 (n).

1 Page 231. 
all the older MSS., as, we may add, it certainly does in all the old printerl editions of the Itinerary, whether foreign or English.

Such, in brief, is an outline of the history of the two questions. One of these, relating to Calleva, is a question of fact; the other, respecting the eight stations, is a question of criticism. We have shown how consiclerable is the weight of evidence, arising from books and MSS., against the retention of Calleva in the heading of Iter XII; and how sreat is the preponderance of opinion that the insertion of the eight stations is an error in the original. We claim, therefore, to have established the fact, that a consensus of opinion has been actually arrived at, to which it behoves topographers to give in their assent, unless they are prepared to displace the eviclence by facts, or to clispute the conclusions by argument. There seems no longer any reasonable doubt that what the librarius ought to have written m what we call the Twelfth Iter, in place of what he did write, was as follows:

\begin{tabular}{|c|c|c|c|c|c|}
\hline Item a Muriduno & o Viroconio & & - & $\mathrm{mpm}$ & xxxvi \\
\hline Lencaro & - & - & - & $\mathrm{mp} \mathrm{m}$ & $x \nabla$ \\
\hline Nido & - & - & - & $\mathrm{mp}$ & $\mathrm{XV}$ \\
\hline Bomio & - & - & - & $m p$ & $\mathrm{xV}$ \\
\hline Iscre leg. & II Augusta & - & - & $\mathrm{mpm}$ & xxviii \\
\hline Burrio & - & - & - & $\mathrm{mp} \mathrm{p}$ & viiii \\
\hline Gobamnio & - & - & - & $\mathrm{mpm}$ & xii \\
\hline Magnis & - & - & - & $\mathrm{mp}$ & xxii \\
\hline Bravonio & - & - & - & $\mathrm{mpm}$ & xxiiii \\
\hline Viroconio & - & - & - & $\mathrm{mpm}$ & xxvii." \\
\hline
\end{tabular}

The sum of the station distance is now found to be 166 miles, being less than the total given in the lieading by only twenty miles.

With this amended text, it is seen at once that the thenry put forward in the first of the papers above referred to, has no locus stancli. There is no longer any need for such a theory, and no longer any ground for it in the nature of the case. Bishop Clifforcl thinlis that Leucarus can be found at Hembury Fort, Niclus at Taunton, and Bomium at Bumham on the Iristol Chamnel. Some of the rensons which oppose this view have been stated hy Mr. Prebenclary Scarth, ${ }^{1}$ and need not be repeated here. To them might be adiled the improbability that the Romans would husband their energy so ill as to make two branches of a military road meeting at an acute angle at Exeter, when one roal would have served their purpose, whereloy to go and to return; or that they would have constructed, not a mere vicinal way, but a main military route through the marshy lowlands of Somerset. But these considerations need not be discussel, if we have good grounds for thinking that Iter XII has nothing to do with. Calleva, and nothing to do with the eight interpolated stations of XV, but is simply a military route leading from Caemarthen in South Wales to Wroxeter in Shropslire. Such was the opinion of Burton and Gale, such the judgment of D'Anville, and such the conclusion arrived at by MM. Parthey and Pinder, who, in their map mark one Muridunum on the sonth coast of Devon, and another on the south coast of Wales; and this we venture to think must be the result to which the written testimony of the past must inevitably lead the careful inquirer.

\section{Journal, vol. xxxvi, p. 325, note.}




\section{ON the Stations of Itrer $\mathrm{XV}$.}

Having thus far indicated the considerations which leal to a removal of the clifficulties attending what we call Iter XII, we are left free to discuss the questions which, in the paper secondly above referred to, have been raised respecting the last of the Britannic Itinera, namely that which is commonly numbered $\mathrm{XV}$.

What we unclertake to show respecting $X V$ is, that a great preponderance of opinion, amounting practically to a consensus', has been established with regard to the two terminal and three of the intermediate and major stations of this route; and that the differenees which still exist, and the questions which still remain to be settled, are differences and questions which relate only to the thrce remaining intermediate and minor stations. And we think that if such a consensus is shown to prevail, then we have a right to expect, that when a writer cleparts as widely as $\mathrm{ML}$. Gordon Hills departs, from established conclusions, he is bound at least to show how those results are to be got ricl of, before he can assume that there is a clear field on which to build a new and aclverse theory.

Briefly statecl, the common interpretation of Iter XV is, that it represents the course of a Roman military roal, from Silchester to Exeter. Mr. Hills' view is, that it represents a road from Silchester to Dorchester. A short review of what has been the current opinion with regard to these eight stations will serve at once to illustrate the extravagances into which Horsley was lecl, and to show to what extent $M I r$. Gordon Hills has deserted the vice antiques of English tradition.

Calueva. This, the starting point of XV, was placed by Burton at Wallingford, by Gale at Henley on Thames, and by Stukeley at Famliam. The clifficulty arose thus. In Iter TII there is only one stage of twenty-two miles between Calleva $\Lambda$ trebatum and Venta Belgarum, Iter XV gives two stages from Calleva, one of fifteen miles to Tindomis, anct then another of twenty-one miles to Venta Bolgarum. Anticipating the conclusion below, that Venta Belgarum is Winchester, there are two altematives, one to place Tindomis at Silchester, and Calleva fifteen miles further away, the other to accept one direct straight road of twenty-two miles from Winchester to Calleva, as Silchester, and to funr Vindomis at some point to the north-west, or the south-cast of this direct road, at a point twenty-one miles from Winchester and fifteen from Silchester. Camden, Burton, Gale, ancl Stukeley preferred the former alternative; Horsley was the first to propose the latter, and his demonstration is now the accepted doctrine. To this conclusion the interesting llawing by Stukeley of the Roman walls ancl amphitheatre at Silchester, no doubt, greatly assisted. Reynolds, incleed, writing in about $1799,{ }^{1}$ and Dr. Bleeke in 1804, ${ }^{2}$ placed Calleva at Realing; but the absence of remains at this town, as contrasted with the extent of the ruins at Silchester and the meeting of numerous roals at the latter place have tumed the ticle of opinion strongly in favour of this last named "chester." 3 An adclitional argument that Calleva is not likely to have been Henley, as Camden, Gale, and the older anthorities supposed, is this. From Calleva, according

1 Iter Britanniarun, p. 292.

2 Archoologia, vol. xv, p. 179.

3 Some other designations will be found in Sir R. Colt Honre's Ancient Wilts, vol, ii (1821), lRoman \&ra, p. 53. 
to the Itinerary, two military roads started westward, and two towards the south. Roman legionaries would be constantly moving along these roads. But Henley is so situated that any one leaving it for the west or south-west must necessarily cross the Thames. It is unlikely that a military base of operations for the soutl and soutl-west of Britian, such as Calleva was, would have been chosen at a place which had this barrier at its gates.

I. Vispours. This is an intermediate station between the two important posts of Calleva and Venta Belgarum. Gale, as we have observed, and also Stukeley, placed Vindomis at Silchester; Horsley adopted Farnham; Reynolds, a residence near Basingstolie, called "The Vine." Sir R. Hoare, however, claims to have found this station on the Port Way. This is a Roman road, not otherwise mentioned in the Itinerary. It leads from Silchester to Old Sarum, and may be seen by the traveller on the South Western Railway, running for miles by the side of the line, between the stations of Grateley and Porton. Vindomis is said by Sir R. C. Hoare to be situated half a mile clue east of Finchley farm, the farm house of which stands exactly on the Port Way. So that a Roman Legion departing from Calleva by Iter XV would march along the Port Way to within two to three miles of Andover, and would then leave that road and strike south-west by another route for Winchester.

II. Venta Belgarum. The identity of Venta Belgarum and Winchester was asserted by Camclen, Burton, Gale, Stukeley, Horsley, Wesseling, Reynolds, Mannert, Sir R. C. Hoare, and Lapie, and is acquiesced in, so far as we know, by all modem authorities. The difficulty is to find a dissentient. Sir R. Hoare having expressed his inability to account for the origin of the word Venta, the point was explained by Dr. Guest, who observes:- "The downs west of the Andred were known by the name of the Gwent, or champaign. There seem to have been several of these Gwents in Britain, and the Romans obtained this name for the capital towns, by turning Gwent into a feminine substantive and then adding the name of the race which inhabited the particular district, as Venta Belgarum, Venta Icenorum, Venta Silurum," \&c. ${ }^{1}$ H.e then proceeds to shew how from Venta Belgarum the Saxons derived their English name of Wintanceaster.

III. BRIGE. This is a small intermediate station between Venta Belgarum, or Winchester, and Sorbiodumum (assumed by anticipation to be Old Sarum). It was found by $\operatorname{Sir} R$. Hoare, as he explains, on the line of Roman road, which is still at intervals visible and traceable between Winchester and Old Sarum. The actual spot is still called Cold Harbour, a little to the north of the actual road, at a point half a mile to the east of Buckholt farm house, which is nine miles from Sarum. This Cold Harbour with its bare walls and roof represented, we may suppose, the actual matatio, where the parochus was bound to be ready with a change of horses and store of forage and provision, whenever an officer of state or a wealthy traveller was on the road. ${ }^{2}$ We have here an instance of a rule, probably generally adopted, that the resting place dirl not stand by the side of the road, but was removed a few hundred yarks from it.

IV. Sonbrodunun. Again a great consensus of distinguished names

Archceological Institute, Salisbury vol., p. 32.

a IIon, Sat. i, 5, 46; Cic. ad Att. v, 16. 
places this station at Old Sarum. To those above enumerated may be added that of Mr. G. T. Clark, in a paper published in 1875.1 Incleed we know of no authority, ancient or modern, who has ever questioned this piece of identification.

$\mathrm{V}$. Vindogladia. This is an intermediate station, lying between Sorbiodunum (Oldl Sarum) and Durmonovaria, which, by anticipation, we fix at Dorchester. The Itinerary places Vindogladia at twelve miles from the former place and nine from the latter. Gale assigned for this station Wimborne, attracted possibly by a fancied resemblance of name. But Wimborne is not on the line of road. The Roman road from old Sarum to the south-west is just here the finest example in the South of Fingland of this class of monmment. It may be traced with the eye, almost from its passage over the Noclder, just above Stoney Stratford, to Woodyates, and from thence along the Blandford road, until it diverges to the south, and crossing the clowns between the villages of Gussage St. Michael and Gussage All Saints, displays itself with the utmost distinctness and even grancleur, as the celebrated Ackling ditch. This road, under the protection of the present owner, the Earl of Shaftesbury, happily remains practically in the same state as it was when described by Stukeley and Sir Richard Hoare; the natural properties of the chalk soil assisting materially in its preservation. It enters the woods of Moor Crichell, and is there for a time lost, but emerges again under the northem ramparts of Badbury, and crossing the Stour at Shapwick, proceeds through Kingston, Winterborne, and over Bere Down to Dorchester. All this is so manifest to the eye, so thoroughly established by demonstration, and so clearly laid down in maps, as to be beyond the reach of controversy. The localities, however, were not known to Gale. Stukeley made search for Vindoglaclia on this line of road, and fancied he found it at Boraston.2 A want of local lnowledge misled Reynolds, ${ }^{3}$ who placed the station at Blandford. Somewhere on the actual, visible, road, the station must have existed, and accordingly we assent to the comclusion of Sir R. Colt Hoare, who claims to liave found it on Gussage Cow Down. ${ }^{4}$ The whole matter is fully discussed in Ancient Witts: ${ }^{5}$ In this conclusion Dr. Guest acquiesces, as appears from his map. ${ }^{6}$

If this be the true position of Vindogladia, it follows that the Itinerary distance from hence to Dorchester, namely eight miles, must be erroneous. For eight, we should have to read something lilke twenty-two. Now it will be remembered that the summary at the head of this Iter, $\mathrm{XV}$, exceeds the sum of the station distances by ten miles. Here then is an opening for a plausible correction. Reading eighteen for eight, the distance would be approximately true. This explanation, however, did not occur, or was not satisfactory to Stukeley, and he started the idea of a "lost station" between Vindogladia and Durnonovaria. The name of this station, Ibernio, he imported from the geographer of Ravenna. To this idea Sir R. C. Hoare also acceded; and funally Mr. Warne, the first

1 Jou'nal, xxxii, 290.

- Itin. Cui:, p. 180. The learned doctor's conversation with the lancllady at the Rose, which convinced him that he had found the locality he was in search of is highly characteristic.

${ }^{3}$ Iter Britann., p. 373.

'In Cruchley's map (not in the Ord. nance) is marked the pair of parallel lines still visible on the down, called "The Curstzs." Vinclogladia is supposed by Sir R. Hoare to have stoud exictly at the sorth-eastern extremity of the Cursus.

5 Roman Ara, p. 29. p. 28 .

Avchceological Institute, Salisbury vol, 
amongst living field antiquaries of Dorset, claims to have found Tbemio near the village of Winterborne Kingston, at about 40 yarcls north of the Icknield Street, here still distinctly visible. ${ }^{1}$ This interesting sicle question does not in any way affect the direction of the actual roact.

VI. Durnonovaria. - With a strange unamimity our English witers have agreed to curtail this name of its proportions, and to speak and write of it as Dumovaria. Tet it may well be that Durno and Noi..... are separate portions of the name. Novaria is the Itinejary name for Novara in North Italy. Durno seems to have been the root of the mames Dornsæetas, and Dorceaster. The consensus that we have noticed for Venta Belgarum, and Sorbiodunum, does not desert us here. All the above authorities, Manmert excepted, agree in assigning this place to Dorchester, where the remains of the city walls, and the amphitheatre, now called Maumbury," abunclantly attest Roman occupation.

VII. MIURIDUNum. This is the fourth of the mansiones, or minor stations, which occur on this military roach, being intermediate between Durnonovaria and Isca Dummuniorum, and distant thinty-six miles from the former fortress, and fifteen from the latter.

Two separate controversies, or groups of questions, have arisen respecting the site of Muriclunum. One of these was initiated by Horsley, who located it out of Devonshire entirely. Having unfortunately adopted the theory that Iter XII was one long continuous route from Silchester to Wroxeter, it was necessary for him on reaching Durnonovaria (which he recognized as Dorchester), to discover some turning point from a western to a northern direction. Now from Dorchester the Roman road runs a visible, manifest course for about nine English, or ten Roman miles, to Eggardon barrow, where, from the ending off of the great chalk district, it enters upon the green-sand, oolite, and lias formations, and thereupon becomes indistinct, and difficult to trace. Half a mile to the north-west of the barrow is the important earthwork of Eggardon, remarkable even in that clistrict of great field fortresses, whence a magnificent view of the south-west coast is obtained, reaching in clear weather to the Start Point. Dr. Stukeley, in about 1720, having followed the course of the Foss road from Bath to the neighbourhood of Hampden or Ham Hill, and having lost sight of it, as every one else loses sight of it, at Dinnington, continued, as we have sail, his joumey to Exeter. Thence he returned by Seaton, of which place he gives an interesting sketch, still in senreh of the western Roman road, which at length he finds, as he says, ${ }^{3}$ " north of Bridport." The remark is rather puzzling, as there is no trace of the road north of Bridport; but upon close examination of the marrative it is plain that what the learned Doctor means is "east of Bridport," namely this very Eggardon Barrow, where the road first became visible to him. Horsley, then, relying wholly upon Stukeley for clescriptions, unable to make the required turn northwards at Exeter, to do which two roads would be necessary, one to arrive at the place, another to depart from it, whereas lie did not know even of one, ${ }^{4}$ was induced to make the turu here at Eggardon, and not only so, but to locate Muridunum at this very place, where Stukeley coming from the west, first found the road. To do this, however, he had to transpose the mileages of the

${ }_{1}^{1}$ Wurne, Ancient Dorset, (1872) p. 201.

2 "Maundbury," Cokier, p. 68.
${ }^{3}$ Page 153.

4 Brit. Rom., p. 462. 
Itinerary. But this was a small matter, as compared with the difficulty which he hal to encounter further on. This was, to find a locality for Isca Dumnuniorum. We need not dwell on the process of reasoning whereby he was led, after hovering for a while over South Petherton and Ilchester, to the melancholy resource of fixing upon Chiselborough Hill, in Somerset, where there is no fortress, no ruin, no earthwork of any kind, British, Roman, English or Danish, and the name of which indicates no antiquity earlier than that of the Saxon

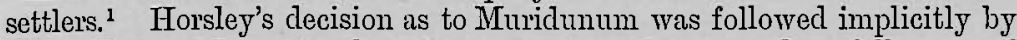
Wesseling. Mannert, the German geographer, another follower of Horsley in the matter of the continuous route, being unacquainted with Sir R. Hoare's then quite recent publication, Ancient Wiltshire, and relying very confidently upon the accuracy of the station distances, having admitted Calleva to be Silchester, thinking Vindomis might possibly be Whitchurch, agreeing that Venta Belgarum was "unquestionably," unstreitig, Winche ter, and that Sorbiodunum was Old Sarum, assigned to Vindogladia, a jiace called Pentridge, near Woodyates; placed Durnonovaria at Moor Cr:chell, Muridunum at Dorchester, and Isca Dumnuniorum at Briclport. Entertaining, as we do, the view expressed as to the unsoundness of the "continuous route" theory, and thinking it can be shown conclusively that Isca Dunmuniorum is Exeter, it is needless to dwell further upon this theory of Mamnert.

The other, and more weighty contention respecting Muridunum is that which, allowing Isca Dummuniorum to be Exeter, differs between assigning this station to Seaton on the one hand, and to Honiton or Hembury Fort on the other. Either place answers tolerably well, perhaps Honiton best, to the mileages of the Itinerary. The first writer who assigned Seaton to Muridunum appears to have been Camden. Whether he ever visited the spot is doubtful. ${ }^{2}$ He conjectures the fact from the signification of the name- "for Moridunum is the same in British that Seaton is in English, namely "A town upon a hill by the sea.'s" So also Sir R. C. Hoare, who says "The exact site of Moridunum is unknown, but the most probable situation is Seaton; and the derivation of the former from mor, sea, and dunum, from duun undè ton, corresponds precisely with Seaton." 4 But, unfortunately for Camden's opinion, Seaton is not a town upon a hill by the sea, but is a town on the western edge of an alluvial flat by the sen. Nor will Sir R. Hoare's assumption, "dun, unde ton," stand the test of modern philology. Probably it was unknown to either of these writers, that Seaton is a comparatively modern word, making its first known appearnnce in the bull of Pope Eugenius respecting Sherborne Abbey, in 1145.5 At the conquest the name of the place was Flveta. ${ }^{6}$ In a charter of Atthelred, in

${ }^{1}$ Ceosol, gravel, shingle, whence presumably the name Chesil Bant.

2 Camden was at Iffarcombe (Ilfracombe) in 1589, where he held for a time a prebend of the church of Salisbury; Biog. Britann., i, 1121.

${ }^{3}$ Gibson's Canden, i, 165 ; and ree Risclon, Ed. of 1811, p. 31.

4 Ancient Wilts, Roman Era, ii, 37 ; and see Bullet, Memoires sur la lanque Celtique (1754) i, 376.
5 The bull enumerates among the possessions of Sherborne "The church of Fleote, with a chapel," and among others the "towns" of "Fleote, Bere, and Seton, with the salt pits and other appurtenances," and the fisheries of "Fleota, Bere, and Seton ;" Hutchins' Dorset, iv, 93.

- Donesday, 104 (1). 
1005, it is called Fleote. ${ }^{1}$ Thus the supposed derivation of Senton from Mordum is seen to be impossible. And why was it called Fleet? Evidently because it was then an estuary which was covered by the sea at every ticle. Gradually as the sea retired from the valley the appellation Fleet became inappropriate, and the new name Seaton came into use. This retirement of the sea from the mouths of the Devonshire rivers was noticed both by Leland ${ }^{2}$ and Camden, ${ }^{3}$ and is too well known to need being insisted on. Certainly in the Axe valley, the sea in 1086 flowed to within one-and-a-half miles of the town of Axminster, for salt was made at the now extinct manor of Haccombfee. Supposing the same natural causes to have been at work before the eleventh century as since, the question arises, Is it probable, as a question of engineering, that the Romans would have projected and made their military road between the fortresses of Durnonovaria and Isea, right through an arm of the sea? Besides this, it is evident upon examination that there never has been, until within the last few years, a crussing of the river by a road, at Seaton. The village is on the sea shore, the church about half a mile from the sea. Two miles above the sea, at Axe Bridge was formerly the only crossing of the river by road in this neighbourhood. There, if at this part of the valley at all, must the Roman road have crossecl, first the Axe, at Axe Bridge, and then the Coly, at Colyforl. Indeed if the coast line from Charmouth, through Colyford, Sidford, Newton Poppleford and Sandy Gate be actually the course of Iter XV from Dorchester to Exeter, then $\Lambda$ xe Bridge answers to Muriclunum much better than Seaton. The authority of Camden was followed unhesitatingly by Gale, Hearne, and Stukeley, and received no check till the publication of the Britamire Romanc, with the extravagant conclusion above stated of placing Muridumum at Eggardon Fort. Reynolds, in the Iter Britanniarum, published in. 1799, was the first writer to suggest Honiton for Muriclunum, ${ }^{5}$ and gradually since his day a conviction has sprung up that the true course of Iter XV was a road which led from Dorchester through Bridport to Charmouth, past Pen Inn and Hunter's Lodge to Yarty Bridge, thence over Shute Hill to Wilmington, and so to Honiton and Exeter. If this be correct, Muridumum must, from the station distances, have been at or near Honiton or Hembury. Dr. Borlase, in 1754, who knew something of the road between Honiton and Exeter, appears to hesitate. "Muriclunum, likely Seaton," he says," "as by the name in British." Dr. William Bennet, the learned Bishop of Cloyne, writing shortly before 1820 , weighs pro and con, with much deliberntion, the reasons so far as they were known to him, and finally gives a doubtful preference to Seaton over Hembury. ${ }^{7}$

The principal grounds for deciding in favour of the inland route are the following:-

Mr. Warne, who traced the course of the road to the limits of Dorsetshire, demonstrates the line which it took after leaving Eggardon Barrow. For a full clescription we refer to his pages, where the matter is thoroughly worked out, having nothing to add to that very clear and convincing

1 K.C.D., $\operatorname{\text {ICCCI}}(\mathrm{vi}, 152)$.

Itin., iii, fol. 41, p. 47, 59.

3 Gibson's Camden, 561.

4 Domesday, $110(2)$.
5 Page 377.

6 Antiquities of Cornwall, i, 296.

7 Lysons' Devon, Intr. p. cccxx. 
clemonstration. ${ }^{1}$ The line he designates is past a place called Spjway (a well-known concomitant of Roman roads, being probably only a vulgar form of Spurway or Spoorweg), and past Wallditch to Bridport; thence to Norecomb Lake, near which is a "Cold Harbour;" thence to Charmouth, where there was an ancient manor called Strete; thence straight to Pen Inn, jast a farm still caller Hogchester. At Pen Inn, the county boundary, Mr. Warne leaves it.

From Pen Im, according to the writer's observation, the road struck a nearly straight course to Hunter's Lodge, along the line of the then tumpike roal, as shewn in the eclition of 1809 of the Ordnance Mโap). Near this portion of the road was discovered in 1818 in a field called Shellacres, on Higher Wild Farm, in Whitchurch purish, a deposit of Roman silver coin. Uncler powers contained in a Tumpike Act passed in 1822, the road was some years afterwarls diverted slightly to the north, but no less since the diversion than before, it forms the northern bounclary of Uplyme parish. This fact shews at least the high antiquity of the road, for the manor of Uplyme was laicl out as early as in A.D. 938.2 From Hunter's Lolge the roacl was carried in nearly a straight line to Yarty Bridge, skirting the clirection of a lane called Woodbury Lane, in the parish of Axminster, passing several places called Wick, and crossing the river's Axe and Yart above their point of confluence, probably near the then heal of the ticle flow. Some traces of this old roal, now clisused, are marked in the Ordnance Map, near the junction of Wick and Woodbury lanes, about halfa-mile south of Axminster, and are to be cliscerned, though now ploughed over, near a farm called Horseleers. From Yarty Bridge the Roman roacl coincided with the old western turnpike road as far as to the hoar stone on Shute Hill. Thence, owing to the nature of the ground, it swervecl to the left but recovered its direct line at Dalwood Jown, anl so passed on, by a place called Moorcot, to Wilmington. Juring this portion of its course, it has for many centuries formed the southern boundary of the parish of Dalwood, which was formerly a ehapel to Stocklancl. These two parishes were formerly, until Sir R. Peel's Act, an outlying nember of Dorset, King Asthelstan having conferrel them both upon Milton Abbey in Dorsetshire, in 1.1). 939. ${ }^{3}$ Dalwood Down is the point to which Dr. Musgrave refers, when he writes (in 1719)- "Et trans Axium" (by which name he means to (lesignate Axminster) "interque illucl et Honiton, vixe militaris certa sunt vestigia." Wilmington is a village which, like the town of Bridport and the village of Charmouth, has grown up on either side of the broal track of the Roman way. Here it forms the bounclary of two parishes. From Wilmington it passed over the hill, straight to Honiton, its course being marked by two or three hoar stones, one or two of which, it is understood, have of late years disappeared.

The result of this demonstration, if correct, necessarily is, to place Muridunum at Honiton. Dr: Bennet, though lie decided in favour of Seaton (not being aware, as the writer conceives, that the Axe

1 Ancient Dorset, p. 145.

MS., Bodl. Woud, i, 212 .

${ }^{3}$ K.C.D., ccelxxv (ii, 211).

4 Antiq. Britanno-Belgice, cap. vii, sec. ii, p. 74. Dr. Musgrave, it shonld be addecl, was nevertheless an advocate of the coast line for Iter XV. The road at Dalwood he takes to have been a branch of the Foss. 
valley was in ancient times an arm of the sea), deliberates between that place and Hembury, not Honiton. How Hembury can be a candidate for Muridunum the present writer cannot understand. Honiton is on the road (as we shall presently see), conveniently situated in the valley, Hembury, which is a strong fortress, is inconveniently situated, two long miles off, on a hill. Why the traveller or the army on its march should have been condemned to mount this hill merely to descend again, is not clear. That the Romans chose their intermediate stopping places near fortresses is likely, and is confirmed by observation. Into a walled town, with gates, the military roads entered; but they were carried past fortresses like Badbury, Weatherbury, and Eggardon in Dorset, and presumably, Hembury in Devon, so as not to break the line of vallation. From the main road a path led up to the fortress in one direction, and another path led away from it in another. The Bishop relied upon the discovery of a presumed Roman lar at Hembury, which is quite consistent with the place having been a Roman fort, but cloes not prove that it was the mension of Mrurichumum.

The most convincing of all reasons why Muridumum should he Honiton is the appearance of the road between that town and Exeter. It would be difficult to find a piece of road with better claims to Roman origin than this. Its rectilinear course, whether as marked on the map, or as seen on the ground, and the way in which it crosses the Otter at Fenny Bridges, mounts the opposite hill, and descends from that point to Exeter, bear the stamp of military road making on an imperial scale. Then there are the names. " Fair Mile" is translated by Dr. Musgrave "milliare aureum," whether with reference to any tradition of a Roman milestone having stood there, the writer is not aware. Strete-way, now Straightway Heal, and Strete, the manor which " taketh his name of the great street way $\mathrm{w}^{\text {cll }}$ passeth through it,"3 are corroborative evidence. This Street, afterwards Street Raleigh, lies on either side of the road, which here divides two parishes, Whimple and Aylesbeare. The former parish is in Cliston, the latter in East Bucleigh hundred. The road is the boundary of several other parishes and of the ancient manor of Nonkerton.

The result, so far as the two roads, the coast or lower and the inland or upper roads, are concerned, seems to be this-the coast line was probably that of the old Icknield Way, and was first used by the Romans when they invaded the country. Afterwards when the district was subrlued, and Isca occupied and fortified, there arose the necessity for a direct military route from Dorchester to Exeter, and the construction of the inland, i.e. the Itinerary, route followed. But the coast line would still continue to be used for non-military purposes. ${ }^{4}$

\footnotetext{
1 The Peutinger Table seems to represent [Mo] "Riduno" as an inland station on an inland road ; and marks it as " $x \mathrm{v}$ " miles from "Isca Dumnonioru,", also an inland town. See Scheyb; and Gough, Topog., vol. i.

"Continuing the sentenceabovequoted, about the "vire militaris vestigia," the learned Doctor adds, "cisque Honiton milliare versus aureum (Fair Mile) manifestissima." Antiq. Brit. Belgice, p. 74.

${ }^{3}$ Sir W. Pole, pp. 161, 168.
}

4 The const road is not rectilinear in direction, nor does it present any Roman names. In 1850, in the parish of Uplyme, on part of Holcombe Farm, were discovered the remains of a villa (Arch. Journal, xi, 49); and it is said that a hoard of Roman coin wass previously found at the same spot. This villa has again been recently exhumed, and its foundations explored. Its position is indecisive, as it is situnted between the two roads, distant about one mile from the lower, 
VIII. Isca Dunnuniorum. That this final station of Iter XV was Exeter, no one, until Horsley (1732), is known to have ever questioned. Bartholomew of Exeter, who became bishop of the see, and died in 1185 , was surnamed Iscanus; so was Joseph of Exeter, the poet, who flourished in about 1210 . Dr: Musgrave, in 1711, writing in Latin, prints "Iscre Dunmoniorum" at the foot of every title page of his book. The sources of Horsley's error have been already too fully dwelt upon to need repetition; it is useful, nevertheless, to see how so carnest and sincere a writer cleals with the question. He admits ${ }^{1}$ the universal consent up to his day. He further admits "some seeming affinity of names," and he adds, "It is true Exeter appears to be Romam, both from the namo and antiquities that have been found there; but I could never yet hear of any military way leading to it or from it, nor indeed the lenst evidence of any further west than what I)r. Stukeley gives the account of, quoted just before; and I see nothing material said to prove Senton to be Roman. It is not easy to know what to make of Ptolemy." Nothing can be more just than these admissions; and in our view nothing more conclusive. The name Exanceaster is incleed sufficient; for if it be difficult to find a single " ceaster," "chester," or "caistor" in England which is not of Roman origin, there is no reason why Exeter should be an exception. Neither could Horsley deny the antiquities, the Roman foundations of the city walls, the Roman streets, ${ }^{3}$ the fragments of inscriptions seen by Leland, ${ }^{4}$ the pavements, ${ }^{5}$ the cella containing penates of bronze, ${ }^{6}$ to which may be added the discoveries, since 1732, of enommous quantities of pottery and glass utensils, and especially of Roman and Greek coins, to the number, it is said, of seventy-five distinct deposits, measuring in one instance half a bushel. ${ }^{7}$ These things could not be gainsaid ; and, incleed, without labouring a point which is clear to demonstration, it is manifest that had Horsley known what we know of the Roman military way which approaches Exeter from Honiton, he too must have given in his adhesion with the rest of the world, whatever might have been the fate of the subsequent stations, which according to his theory formed part of the long circuitous route from Calleva to Uriconium.

The result of what may be termed the literary history of Iter XV is thus found to be a general consensus as to the position of the five main castella or fortified citadels, and some uncertainty as to the locality of the four minor halting places. Of three, the position rests solely on the demonstrations of Sir R. C. Honre, whilst the fourth, Muridumum, may be deemed to be still sub jurlice.

and two miles from the higher. At Seaton, on the other hand, direct proofs of Roman, or Romano-British occupation have recently been brought to light. Specimens are preserved in the Albert Museum, Exeter.

1 Essay on Ptolemy, Brit. Rom., p. 371.

2 Brit. Rom. p. 462.

${ }^{3}$ Mapped by Mr. Freeman, Norman Conquest, iv, 153 ; suloject to corrections by Mr. Kerslake, Journal (1873), xxx, 21.1 .

4 "There appere 2 fragmentes of Inscriptions of the Romaines sette by chaunce of later tymes in the Town Waulle wid" (vide?) " on the bak side of [this] House sumtyme longging to the Blak Freres. One of the[m stan]dith in a Tower of the Waul, [the] other is in [the Waul hardby (the Towrre]." Itin., vol. iii, fol. 33, p. 47 of the 2 nd edition by Hearne.

5 Stukeley, i, 151 ; Jeulins' Hist. of Excter, p. 6.

o Arihceologia, vol. vi, 1 .

7 Shortt, Sylia Antiqua Iscana, pp. 19. 78, 93-108, 110 ; Collectanea, p. 85 
This funal conclusion respecting Iter $\mathrm{XV}$ seems to be in all respects satisfactory. What course can be imagined more consistent with Roman practice than to erect a fortress within the territories of each tribe, and then to link together these fortresses by clirect military roads, forming a network of clominion over the whole island? Thus Calleva wonld dominate the Atrebates, Gwent or Venta the Belga, Sorbiodunum the tribes of the plain and of the Wily valley, Durno the Durotriges, and Isca the Dummunii. And when at length the iron hand of Rome was withdrawn, and a new set of conquerors appeared on the scene, still the districts would be governed from the ancient fortresses, and whilst Wintanceaster became the capital of all TVessex, Searobyrig would remain the capital of the ITilsietas, Dornceaster of the Dornsæetas, and Exanceaster of the Defnas.

\section{View of Mir. Golrdon Hiris.}

In this time-honoured and reasonable view of the case $\mathrm{Mr}$. Gorclon Hills by no means concurs. As if the subject were untouched by authority, unstudiel by the labours of generations, perfectly virgin soil, he takes up Iter $\mathrm{XV}$, and by a novel process of reasoning arrives at the following results. Calleva he allows to be Silchester; for Vinclomis he gives Alton in Hampshire; Venta Belgarum he places at Havant; Brige at Titehfield; Sorbiodumum at Bittem; Vindogladia at Winchester; Durnonovaria at Romsey; Muridunum at VTareham; and Isca Dumnuniorum at Dorchester. This is more extravagant than even. Horsley, for if it was hard to find Dumnunii out of their own region, though no further off than at Chiselborough in Somerset, "so nenr the borters," as Horsley observes, how much harder is it to find them from twenty to thirty miles off, amongst the Durotriges. And this too in Roman times, when one subject tribe was not likely to be permittecl to invacle the territories of its neighbour. ${ }^{1}$ And where is the Dorsetshire Isca? Horsley found a rivulet called the Axe, six miles from Chiselborough; but many times six miles from Dorchester must be traversed in order to find an Isc, an Axe, or an Usk. Noreover, of what strategic value would such a contracted circuit as this have been to the Romans? For we are dealing now, not with roads made for tracle, or the convenience of residents, but with a branch of a military system which extended from Britain to Syria, and from Spain to the Black Sea. That great fortresses would such a route as this unite? How could the tribes of the southwest have been controlled from so clistant a post as Dorchester ?

\section{On the Abbreitation "M t M."}

Mr. Gorlon Hills relies very strongly upon measurements made exactly to suit the number of Roman miles appencled to the name of each station in the Itinerary. He seems not to be aware of the fact, which lias been very little noticed by eminent topograpliers, even by Horsley and Sir R. C. Hoare, that the abbreviation " $\mathrm{m} 1$ " m" preceding the numeral does not mean "milia passuum" at all. It means "milia plus

\footnotetext{
1 There was a time indeed when the Dumnunii, rtıled by independent native princes, did " conquer certain tracts of Britain lying beyond the boundaries of
}

their proper territonies"; Guest, Arch. Joumal, vol. xvi, j. 130. But this was not till after the Romans had ceused to be their masters. 
minus," so many miles " more or less;" "about so many miles." So that all accurate measurements with rule and compass are by the conditions of the problem entirely out of the question. As this is a somewhat important matter, and has been little attended to, we may bo excused for dwelling upon it somewhat particularly. It is noticed by MM. Parthey and Pinder in their preface. $\Lambda$ fter observing that the abbreviation it with which each new route begins has been erroneously rendered iter, wherens it really stands for itom; they proceed-

"To the number of miles are prefixed in the MSS. the letters $m p m$ or $m p$. That this is to be rightly explained by milice plus minus appears from the Itinerary of Jerusalem, which reads lengres plus minus: Surita, nevertheless, on the authority of a MLS. in the Escurial, took pains everywhere, insteal of $m \cdot p m$, to write s. $P$. which is the proper abbreviation for milia passum.m. He was followed by Wesseling, who ought to have known better."1

Accordingly, in turning to the Itinerary from Bordeaux to Jerusalem, we find in the title the phrase "leugas plus minus;" and at the begimning of the Itinerary of Antoninus many of the MSS. write out full in the first and second lines the expression "milia plus minus" which they afterwarls abbreviate to " $\mathrm{m} \mathrm{p}$ m." The point was noticerl by Roger Gale, the son, in his preface to his father's posthumous work, though Dr. Giale himself seems to have been unaware of it; and Hearne, in his eclition of the Itinerary, invariably prints "milia plus minus" at length in the headings of the Itinera. But since this date, circ. 1710, cvery English writer, so far as the writer is aware, has fallen into the inaccuracy of treating these rough estimates as if they were carefully measured mile distances; and it is startling to think of the amount of minute calculation which must be consigned to oblivion by this rectification alone.

\section{ON the Longitudes of Ptolemy.}

Mr. Gordon Hills, however, does not rest wholly on the mileages of the Itinerary ; he leans more confidently on the longitudes assigned to various places by Ptolemy. But will this ground of support prove to be more valid than the other? Let us consider for a moment what the longitudes of Ptolemy really were. That Ptolemy made astronomical observations at Alexandria with the astrolabe is recorded by the historians of astronomy. ${ }^{3}$ But the same authorities tell us that Ptolemy had no clocks. Not that the Greeks and Romans had not water clocks, clepsyylrce, just as they had shaclow clocks or sun-dials. But the kind of clock that would be needed to determine the longitude would be a time-keeping clock or chronometer, which set at Alexandria would keep time for any other part of the world to which it might be carried. Can we believe that Ptolemy possessed such an instrument as this? The only other possible method was a simultaneous observation made at Alexandria and at the place of which

\footnotetext{
1 "Milium numeris codices preponunt $\mathrm{mp} \mathrm{m}$ vel $\mathrm{m} \mathrm{p}$; quod recte per 'milia plus minus' explicari vel inde patet quod in Itinerario Hierosolymitano legitur 'leugas plus minus.' Quamquam Surita ex. auctoritate codicis Scorialensis ubique pro $\mathrm{m} \mathrm{p} \mathrm{m}$ scribendum curavit ג.P., quod
}

'milia passuum ' interpretatur. Eum secutus est Wesselingius, etsi meliora edoctus "; Prof., p. xi.

2 Pref., p. v.

${ }^{3}$ See a paper by Captain Drayson, Monthly Notices of the Astronomical. Society, xxviii, 207. 
the longitude was required, by two observers, of some astronomical event, such as an eclipse of the moon. Is it credible that such a series of observations was made by Ptolemy and his assistants for every place of which he has purported to give the longitude? If not, it must follow, that what are called the longitudes of Ptolemy are not longitudes in the modem sense of the term at all. Whereas the moderns estimate the sea or land space over which they travel by means of clocks oi ril real observations, all that Ptolemy did or could do was to reverse the process, and calculate his meridian distances from the estimated extent of land or sea passed over in travelling. This does, in fact, nppear from Chapters xii and xiii of Ptolemy's treatise. So that his so-called longitudes were mere estimates of the true longitude, and a system of elaborate calculations based upon such a foundation must result in faulty calculations. Dr. Hutton, in his Philosoplizeal Dictionary, ${ }^{1}$ mentions the remarks of very old critics, Collarius and Salmasius, who question Ptolemy's accuracy, on the ground that he delivers himself with the same fluency and certainty concerning things at the remotest distances, which it was impossible he could know anything of, as he does concerning those which lay nearest to him. But we need not attribute either carelessness or pretentiousuess to Ptolemy in order to account for the many errors into which he fell, and which render it impossible to rely with certainty upon his indications of places in Britain. Neither is it his fault that a word not used by him, but adopted as a translation of his process of measurement, should have since come to signify a system of scientific observation of the nature of which he had no idea.

Nor can we imagine that the work of Ptolemy, immeasurably superior as it was to those of his predecessors, ever went through the test of every day service, as did the Itinerary, called that of Antoninus. Compiled as the Itinerary was, from the accumulated notes, preserved at Rome, of military commanders, beginning possibly with Julius himself, and published probably by Marcus Aurelius Antoninus, ${ }^{2}$ afterwards sumamed Caracallus (son of Septimius Severus, our British Roman wall builder), it did not remain a stereotyped work. That it was altered from time to time is proved by the accurrence in it of such names as Diocletianopolis, Maximianopolis, Constantinopolis. To such alterations may perhaps be attributed the differences between the summaries of miles and the sums of the station distances. The inference is tolerably plain, that it was a document in constant use, subject to revision from time to time. With such a practical working road book as this, the measurements of the geographers cannot be placed in competition. If the statements of the Itinerary on the one hand, and of Ptoleny or the Ravennate on the other, come into conflict, the presumption must be against the geographers.

The result of all that is extant on this subject seems to shew that in fact a definite conclusion has been arrived at on all the main features of the case. That conclusion is not, we think, likely to be disturbed by either of the essays above referred to. Certainty, so far as it has been attained, will not readily be abandoned. The lnot of confusion has been disentangled, and it is useless to revert to complications which are obsolete. An adoption, on the one hand, of errors into which the author of the Britannia Romana was unfortunately led, for want of the informa-

${ }^{1}$ Art. Ptolemy.

2 Parthey and Pinder, Praef. p. vi. 
tion we possess, or an atttempt, on the other hand, to supersede a long current of observation by a resuscitation of the measurements of the geographer Ptolemy, must be regarded as too retrogressive a step for acceptance at the present day.

\section{CHRONOLOGICAL LIST OF EDITIONS AND AUTHORS.}

\begin{tabular}{|c|c|c|c|}
\hline Paris Edition (Stephanus) & & & 1512 \\
\hline Venetian Edition (Aldlis) & $\ldots$ & $\ldots$ & 1518 \\
\hline Florentine Edition & $\ldots$ & $\ldots$ & 1519 \\
\hline Lyons Edition _... & $\ldots$ & $\ldots$ & $1536 ?$ \\
\hline Basle Edition (Simler's notes) & $\ldots$ & $\ldots$ & 1575 \\
\hline Harrison in Holinshed's Chron & 1st Edition & & 1577 \\
\hline Ib. $\quad \ldots$ & 2nd Edition & $\cdots$ & 1587 \\
\hline Camden, Magna Britamnia & 1st Edition & $\ldots$ & 1586 \\
\hline Cologne Edition (Surita) & $\ldots$ & $\cdots$ & 1600 \\
\hline Leyden Edition (Bertius) & $\cdots$ & $\cdots$ & 1618 \\
\hline Burton $\quad \ldots$ & $\ldots$ & $\ldots$ & 1658 \\
\hline Gale & $\ldots$ & ... & 1709 \\
\hline Hearme $\quad \ldots$ & $\ldots$ & ... & 1710 \\
\hline Musgrave, Antiq. Britanno-Bel & $\ldots$ & ... & 1719 \\
\hline Stukeley, Itinerarium, 1st Edit & $\ldots$ & $\ldots$ & 1724 \\
\hline Horsley, Britannia Romana & $\cdots$ & $\cdots$ & 1732 \\
\hline Wesseling $\quad \ldots$ & $\ldots$ & ... & 1735 \\
\hline C. J. Bertram addresses Stukel & & ... & 1747 \\
\hline Borlase, Antiquities of Cornwa & $\ldots$ & $\ldots$ & 1754 \\
\hline Richard of Cirencester, Publica & n of spurious & ... & 1757 \\
\hline Milles, Exeter Antiquities, Arc & ologia $\quad \ldots$ & ... & 1779 \\
\hline Reynolds, Iter Britanniarum & $\ldots$ & $\ldots$ & 1799 \\
\hline Hoare, Sir R. C. & $\ldots$ & $\ldots$ & 1821 \\
\hline Bennet, Bishop of Cloyne (Int & o Iysons' Devon) & $\ldots$ & 1822 \\
\hline Mannert $\quad \ldots$ & $\ldots$ & $\cdots$ & 1822 \\
\hline Shortt, Sylva Iscana, and Colle & nea & $\cdots$ & 1841 \\
\hline Lapie, Recueil des Itinéraires & ... & ... & 1845 \\
\hline Parthey and Pinder & & & 1848 \\
\hline Guest; Salisbury Volume & $\cdots$ & & 1849 \\
\hline Bertram's Forgery exposed & $\ldots$ & $\ldots$ & 1852 \\
\hline Woodward's Letters on R. of & ncester & $\cdots$ & 1866 \\
\hline Warne's Ancient Dorset & $\ldots$ & $\ldots$ & 1872 \\
\hline
\end{tabular}

